\title{
Acute Toxicity (LC50) Of Cyhalofop Butyl on Gambusia Holbrooki Utku GÜNER ${ }^{1 *}$
}

\begin{abstract}
Cyhalofop butyl is a synthetic herbist. This herbicide is a systemic herbicide and is used in weed control especially on celtic agriculture. In this study, the acute toxicity $\left(\mathrm{LC}_{50}\right)$ of this herbiest (Chillinger 200 EC 200, Cyhalofop butyl) was investigated, which is currently used intensely in the fight against herbists in Thrace region, including Cyhalofop butyl. Acute toxicity ( $\mathrm{LC}_{50}$ value) for this herbicide has been investigated in the common mosquito fish (Gambusia holbrooki) in Thrace Region. Lethal Dose 50 experiments were performed in 3 replicates in static test runs (water temperature 27.70 $\pm 0.56{ }^{\circ} \mathrm{C}$, water $\mathrm{pH} 8.88 \pm 0.37$, and conductivity $718.25 \pm 21.113 \mu$ hos). The experiment results obtained for Chillinger 200 EC during the experiments were evaluated by Trimmed Spearman-Karber method. 96-hour $\mathrm{LC}_{50}$ value for the mosquito fish Gambusia holbrooki was calculated as $4.140 \mathrm{ppm}$.
\end{abstract}

Keywords: Cyhalofop butyl, Gambusia holbrooki, Lethal Dose 50

\section{Cyhalofop butyl in' Gambusia holbrooki üzerindeki Akut toksisitesi (LC50)}

ÖZET: Cyhalofop-butyl sentetik herbist grubundadır. Bu herbisit sistemik bir herbisit olup özelikle celtik tarımında yabancı ot mücadelesinde kullanılmaktadır. Bu herbist sucul ekosistem için oldukça toksitir. Bu çalışmada Cyhalofop butyl içeren halen Trakya bölgesinde herbist mücadelesinde yoğun olarak kullanılana bu herbistin (Chillinger 200 EC , 200 Cyhalofop butyl) akut toksitesi (LC50) araştırılmıştır. $\mathrm{Bu}$ herbisit için akut toksisite ( $\mathrm{LC}_{50}$ değeri) Trakya Bölgesinde yaygın sivrisinek balığında (Gambusia holbrooki ) araştırılmıştır. Lethal Doz 50 deneyleri 3 tekrarlı olarak statik deney koşularında (su sıcaklığı $27.70 \pm 0.56{ }^{\circ} \mathrm{C}, \quad \mathrm{pH} \quad 8.88 \pm 0.37$, iletkenlik 718.25 $\pm 21.113 \mu$ hos) gerçekleştirilmiştir. Deneyler buyunca Chillinger 200 EC için elde edilen deney sonuçları Trimmed Spearman-Karber yöntemiyle değerlendirilmiştir. Sivrisinek balığı , Gambusia holbrooki, için 96-saat

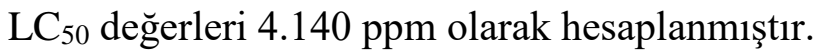

Anathar kelimeler: Cyhalofop butyl, Gambusia holbrooki, Lethal Doz 50

${ }^{1}$ Utku GÜNER (Orcid ID: 0000-0003-4135-2486), Trakya üniversitesi, fen Fakültesi Biyoloji Bölümü, Edirne, Türkiye *Sorumlu Yazar/Corresponding Author: Utkuu Güner, e-mail: uguner@trakya.edu.tr

Geliş tarihi / Received: 12-04-2020

Kabul tarihi / Accepted: 15-06-2020 
Acute Toxicity (LC50) Of Cyhalofop Butyl On Gambusia Holbrooki

\section{INTRODUCTION}

In today's modern agriculture the use of herbicides (pesticides) is inevitable. However, when using pesticides, both the protection of the product against diseases, pests and weeds and the negative effects on human and ecosystem should be evaluated together. Pesticides not only can control pests but also may have negative impact to the environment (Çebi, et al., 2017). Pesticides introduced into aquatic ecosystems can cause massive death or diseases of fish (Güner, 2012; Güner, 2016). Herbicides are one of the main groups of pesticides which are used in many parts of the western part of Turkey (Thrace region) to control wide variety of rice at application. Unfortunately, herbicides are spreading in the areas they are used and effected lakes, rivers and ponds creating hazardous effects to the aquatic fauna including fish. These toxic chemicals have been reported to create major effects (acute and chronic) especially on fish health (Atabey, 2016).

Cyhalofop butyl is a herbicide having outstanding selectivity between rice and Echinochloa sp. , even under conditions in which rice seedling roots are directly exposed to paddy water (Matsumoto, et al. 1993). Cyhalofop-butyl, CAS number 122008-85-9, is an herbicide widely used in weed control, especially in control of grasses in rice at application rates of $150 \mathrm{~g} \mathrm{ha}^{-1}$, mainly against almost all Echinochloa sp. on western part of Turkey (Thrace Region). This herbicide is applied to pans that have been watered by spraying with herbicides with appropriate spraying tools and equipment after weeding against weeds that are especially problematic in paddy cultivation areas. Heavy use of agrochemicals, especially pesticides, has been identified as one of the main problems in rice culture in Thrace region (İnan, 2012).

The present test animal Gambusia holbrooki inhabits standing to slow-flowing water but are most common in vegetated ponds, lakes, and rice culture areas (Özuluğ, and Gaygusuz, 2013; Kurtul and Sarı, 2019).

Cyhalofop-butyl is one of most used herbicide widely employed in paddy fields in Thrace region, and can transfer into lakes and river environments via waterways. However, details of the environmental risk and aquatic toxicity of Cyhalofop-butyl (especially these herbicide commercial formulations) have not been fully investigated. Since it is a widespread organism and is used for biological control of mosquito (and to demonstrate acute toxicity of non-target organisms), this study was undertaken to evaluate acute effects of Cyhalofop-butyl on G. holbrooki under static test conditions.

\section{MATERIALS AND METHODS}

This test organism, G. holbrooki which has a wide distribution in Thrace region inhabits standing to slow-flowing small water; most common in vegetated ponds and lakes, backwaters and quiet pools of streams and paddy field.

In this study, about 100 adult G. holbrooki specimens were collected from Güllapoğlu Lake, Edirne. They were transported in well-aerated large containers $(201)$ into the laboratory, and then kept here for 7 days for acclimatization before the start of the experiments. The fish used were adults of both females and males between 22 and $37 \mathrm{~mm}$ total length (about $<1 \mathrm{~g}$ ). They were transferred to glass aquarium (stock aquarium dimensions 10x40x50 cm, 20 l) in the aquarium room and maintained at 26 ${ }^{\circ} \mathrm{C}$ and 16:8 light: dark regime (Güner, 2009).

The experiments were conducted in 21 disposable plastic tanks, each containing 21 test solutions with different concentrations of the test substances (Cyhalofop-butyl commercial formulation: Chillinger 200 EC) or negative control, and 5 organisms were tested in one plastic tank. The experimental fishes were divided into five groups. The first group was kept in fresh untreated water and used as a control while the other four groups were exposed to the selected dose concentrations. The 
fishes were exposed to 1, 2.5, 5, 10 ppm of Cyhalofop-butyl for 5 days (96 hours) for $\mathrm{LC}_{50}$ test. All experiments were performed with three replicates. Tap water was aerated for dechlorinating pretreatment by air pump for over $24 \mathrm{~h}$. The exposure lasted for 96 hour, and symptoms and mortality were recorded at 24,48 , and 96 hours post treatment.

The following herbicide was used in this study: Cyhalofop-butyl; molecular formula $\mathrm{C}_{20} \mathrm{H}_{20} \mathrm{FNO}_{4}$ (CAS no: 122008-85-9), emulsion concentration is $50 \mathrm{mgL}^{-1}$ (fig 1). Commercial grade Cyhalofop-butyl (Chillinger $200 \mathrm{ec}$, proved by Agrobest Grup, Turkey) was used in this study.

Figure 1. Cyhalofop-butyl (Chillinger $200 \mathrm{EC)} 50 \mathrm{gL}^{-1}$ : butyl (2R)-2-[4-(4-cyano-2fluorophenoxy) phenoxy] propanoate.

Statistical analysis was performed using $\mathrm{LC}_{50}$ Trimmed Spearman-Karber Program (1.5 version). The median lethal concentrations, $\mathrm{LC}_{50}$ (96 hour) and 95\% confidence interval were calculated statistically by the Trimmed Spearman-Karber method (Hamilton, Russo, \& Thurston, 1977).

\section{RESULT AND DISCUSSION}

During the experiments, the physicochemical parameters of water were quite constant; dissolved oxygen level $12.17 \pm 1.29 \mathrm{mgL}^{-1}$, water temperature $27.70 \pm 0.56{ }^{\circ} \mathrm{C}$, water $\mathrm{pH} 8.88 \pm 0.37$, and water conductivity $718.25 \pm 21.113 \mu$ hos. $\mathrm{LC}_{50}$ experiments were performed with three replicates (Table 2). No deaths were observed in the control group during the experiments (all three replicates). At the end of 96 hours, lethal concentration 50 was calculated with a special computer program (Hamilton et al., 1977) (Table 1).

Table 1. Water physicochemical parameters.

\begin{tabular}{lcccccccc}
\hline \multirow{2}{*}{ Parameter } & \multicolumn{4}{c}{ Time } & Mean & SD & Max & Min \\
\cline { 2 - 5 } & $\mathbf{0 ~ h}$ & $\mathbf{2 4 ~ h}$ & $\mathbf{4 8} \mathbf{~ h}$ & $\mathbf{7 2 ~ h}$ & & & & \\
\hline $\mathrm{pH}$ & 8.51 & 8.5 & 9.25 & 9.24 & 8.88 & 0.37 & 9.25 & 8.5 \\
Condactive $(\mu \mathrm{hos})$ & 704 & 717 & 753 & 699 & 718.25 & 21.11 & 753 & 704 \\
Temparatute $\left({ }^{\circ} \mathrm{C}\right)$ & 27.5 & 28 & 26.9 & 28.4 & 27.70 & 0.56 & 28.4 & 26.9 \\
\hline
\end{tabular}

The median lethal concentration, $\mathrm{LC}_{50}$ (for 96 hour) and $95 \%$ confidence interval were calculated as in Table 2. 
Table 2. Results of the $\mathrm{LC}_{50}$ tests (R1, R2 and $\mathrm{R} 3$ are the replicates)

\begin{tabular}{ccccccc}
\hline \multirow{2}{*}{ Concentrations } & Number Exposed & \multicolumn{5}{c}{ Mortalities } \\
\cline { 2 - 5 } & & R 1 & R 2 & R 3 & Mean & Mortalite \\
\hline $0.0 \mathrm{ppm}$ & 5 & 0 & 0 & 0 & 0 & $\% 0$ \\
$1.0 \mathrm{ppm}$ & 5 & 0 & 0 & 0 & 0 & $\% 0$ \\
$2.5 \mathrm{ppm}$ & 5 & 0 & 0 & 0 & 0 & $\% 0$ \\
$5.0 \mathrm{ppm}$ & 5 & 4 & 3 & 4 & 4 & $\% 80$ \\
$10 \mathrm{ppm}$ & 5 & 5 & 5 & 5 & 5 & $\% 100$ \\
\hline
\end{tabular}

At the end of the tests (96 hours, three repetitions), calculated lethal dose 50 values and doseresponse graph of Cyhalofop butyl are shown in Table 3 and Figure 2.

Table 3. Calculated 96-hour $\mathrm{LC}_{50}$ values.

\begin{tabular}{ll}
\hline $\mathrm{LC}_{50}$ value Trim & $\% 40.00$ \\
Estimates $\mathrm{LC}_{50}$ value & $4.14 \pm 1.731 \mathrm{ppm}$ \\
$\% 95$ lower confidence & $4.751 \pm 0.250 \mathrm{ppm}$ \\
$\% 95$ upper confidence & $0.113 \pm 0.605 \mathrm{ppm}$ \\
\hline
\end{tabular}

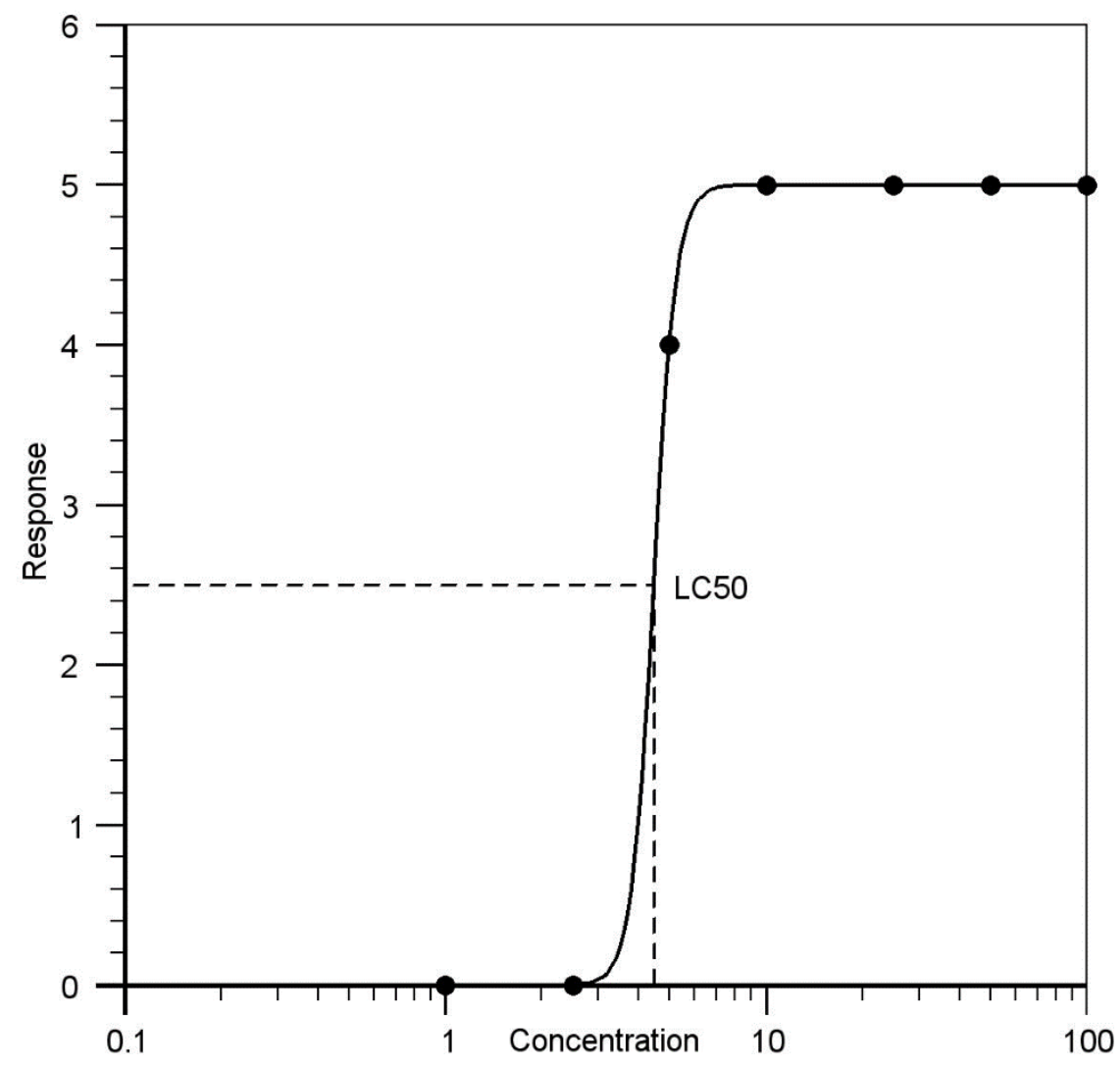

Figure 2.Dose-response graph of Cyhalofop butyl herbicide.

This research evaluated the cytolofob -butyl acute toxic effect 96 hours $\mathrm{LC}_{50}$ value. Low $\mathrm{LC}_{50}$ value indicates that the active substance has high acute toxicity. The $\mathrm{LC}_{50}$ concentrations of cyhalofopbutyl in 24 h, 48 h, and 96 h were 63.15, 51.91, and 34.41 ppm, respectively on Daphnia carinata. Daphnia magna, 21-day NOEC (the no observed effect concentration) value was 0.13 ppm (Li and Yuan, 
2017). Another study showed that Daphnids (Daphnia magna; 48h EC $\mathrm{E}_{50} 63.62 \mathrm{ppm}$, measured), green algae (Selenastrum capricornutum; $72 \mathrm{~h} \mathrm{EC} 50=9.71 \mathrm{ppm}$, measured), blue-green algae (Anabaena flosaquae; $72 \mathrm{~h} \mathrm{EC}_{50}>8.44$ ppm, measured ester \& acid)), duckweed (Lemna minor; $14 \mathrm{~d} \mathrm{EC}_{50}>5.3 \mathrm{ppm}$, measured ester \& acid), and diatoms (Navicula pelliculosa; $120 \mathrm{~h} \mathrm{EC}_{50}=1.33 \mathrm{ppm}$ ).

Cyhalofop-butyl was toxic for fish and some aquatic animals. (LC $\mathrm{L}_{50}$ values from 1.0 to $10.0 \mathrm{ppm}$ in the most sensitive species). 96 hours $\mathrm{LC}_{50}$ value of Cyhalofop-butyl was $11.0 \mathrm{ppm}$ for Oncorhynchus mykiss (Rainbow trout), on semi-static test (Authority, 2015). Acute toxicity of cyhalofop-butyl varies by the organism type. Acute toxicity of Cyhalofop-butyl has been tested on a range of aquatic animals including the rainbow trout (Oncorhynchus mykiss; $96 \mathrm{~h}, \mathrm{LC}_{50}=1.65 \mathrm{ppm}$, nominal), the bluegill sunfish (Lepomis macrochirus, $96 \mathrm{~h}, \mathrm{LC}_{50}=0.637 \mathrm{ppm}$, measured). Cyhalofop-butyl has toxicity to some aquatic organisms, with a 96-h LC $\mathrm{LC}_{50}$ value of $0.79 \mathrm{ppm}$ to Lepomis macrochirus, and a 48-h $\mathrm{LC}_{50}$ value of up to 2.7 ppm to Oncorhynchus mykiss (Zhu et al., 2015). 96-h LC $_{50}$ value of cyhalofop-butyl to clover duckweed was $5.04 \mathrm{ppm}$. Another work tested the acute toxicity of Cyhalofop-butyl to Rana limnocharis tadpoles and found that with $24 \mathrm{~h}$ and 48-h LC 50 values of 0.718 and $0.677 \mathrm{ppm}$, respectively (Wu et al., 2011).

Cyhalofop-butyl causes acute toxic effects not only in adults but also in fish embryos. The $96 \mathrm{~h}-$ LC $_{50}$ value of Cyhalofop-butyl to Danio rerio embryos was $0.57 \mathrm{ppm}$. Exposure to Cyhalofop-butyl also caused developmental abnormalities, such as abnormal spontaneous movement hatching inhibition, depressed heart rates, and growth regression (Zhu et al., 2015). The mortality rate of embryos of the Yellow River carp (Cyprinus carpio var.) was increased on exposure to Cyhalofop-butyl and was significantly higher in the 1.6 and $2.0 \mathrm{ppm}$ treatment groups over $48 \mathrm{~h}$. All of the embryos of the 2 $\mathrm{mgL}^{-1}$ treatment group died within the $48 \mathrm{~h}$ post-hatching stage (Xia et al., 2018).

The toxic mechanism of Cyhalofop butyl may be similar to that of organophosphorus pesticides with their neurotoxic effects (Rajyalakshmi et al., 1996). The toxicity of organophosphates takes place in the inactivations of acetylcholinesterase (AChE), where they combine with the enzyme that forms an irreversible enzyme inhibitor complex. Another important toxic mechanism of action may be that pesticides affect the resynthesize of Acetylcholinesterase (Colovic, et al., 2013)

Acute toxicity data are very important in the evaluation of toxic substances. In particular, herbicides should be investigated for their acute toxicity of commercial formulations in natural fish populations. Further studies with direct toxicity testing methods on fish will be very useful in assessing the possible ecological risks of these pesticides due to changing physicochemical parameters and chemical properties of pesticides.

In conclusion, the present study evaluated lethal dose for 96 hours effects of one of most used synthetic herbisit on mosquitofish. This herbicide is often used in mosquito fish habitats. The calculated value of the 96-hour LC $_{50}$ of Cyhalofop-butyl was 4.140 ppm (Table 3). It should be taken into consideration that mosquito fish, which are biological control agents, will be affected by this herbicide toxicity.

\section{REFERENCES}

Atabey T, 2016. Edirne yöresinde üretilen pirinçlerde pestisit tayini. (Master Tezi), Namık Kemal Üniversitesi Fen Bilimleri Enstitüsü, Yüksek Lisans Tezi (Basılmış).

Authority EFS, 2015. Conclusion on the peer review of the pesticide risk assessment of the active substance cyhalofop (variant evaluated cyhalofop-butyl). EFSA Journal, 13(1), 3943.

Çebi ÜK, Özcan C, Gürbüz MA, Selçuk Ö, 2017. Trakya Bölgesi’nde Ayçiçeği Tarımında Kullanılan İmazamox Herbisit'inin Toprak Ortamında Kalıntı Düzeylerinin İzlenmesi ve Değerlendirilmesi. SOIL WATER J, 6(2): 32-39. 
Colovic MB, Krstic DZ, Lazarevic-Pasti TD, Bondzic AM, Vasic VM, 2013. Acetylcholinesterase inhibitors: pharmacology and toxicology. Curr. Neuropharmacol., 11(3): 315-335.

Güner U, 2009. Determination of lambda cyhalotrin (Tekvando 5EC) 96 hour lethal concentration 50 at Gambusia affinis (Baird \& Girard, 1853). J Fishscicom., 3(3): 214.

Güner U, 2012. Determination of 24-and 48-hour LC50 values of diazinon in Gambusia affinis (baird \& girard, 1853). Arhiv Za Higijenu Rada i Toksikologiju, 63: 32.

Güner U, 2016. Behavioral differentiation induced by insecticide lambda-cyhalothrin in mosquito fish, Gambusia affinis. LimnoFish. , 2(1): 11-17.

Hamilton MA, Russo RC, Thurston RV, 1977. Trimmed Spearman-Karber method for estimating median lethal concentrations in toxicity bioassays, Environ Sci Technol, 11(7): 714-719.

İnan İH, 2012. Trakya Bölgesinde Tarım ve Hayvancılığın Durumu, Discussion Paper, No. 2012/16, Turkish Economic Association, Ankara.

Kurtul I, Sarı, MH, 2019. Gambusia holbrooki (Sivrisinek balığı)'nin Türkiye'deki Dağılımına Katkılar. LimnoFish, 5(3): 170-180.

Li J, Yuan L, 2017. Acute toxicity study of glyphosate and cyhalofop-butyl to Daphnia carinata. Acta. Phys. Sin (9): 16.

Matsumoto T, Matsuya K, Katahashi H, Kondo N, Imai Y, 1993. Cyhalofop butyl: grass herbicide-field performance in rice in Japan. Paper presented at the Proceedings I of the 10th Australian Weeds Conference and 14th Asian Pacific Weed Science Society Conference, Brisbane, Australia, 6-10 September,

Özuluğ M, Saç G, Gaygusuz Ö, 2013. İstilacı özellİkteki Gambusia holbrooki, Carassius gibelio ve Pseudorasbora parva (Teleostei) türleri İçin Türkiye'den yeni yayilim alanları. Ist. Uni. J. Fish. \& Aqu. Sci., 28: 1-22.

Rajyalakshmi T, Srinivas T, Swamy K, Prasad NS, Mohan PM, 1996. Action of the herbicide butachlor on cholinesterases in the freshwater snail Pila globosa (Swainson). Drug Chem Toxicol., 19(4): 325-331.

Wu C, Zhao X, Wu S, Cheng L, Wang Y, Chang T, Ping L, 2011. Toxicity and risk of herbicide cyhalofop-butyl on Rana limnocharis. Acta Agri. Zhejiangensis, 23(4): 771-775.

Xia X, Wang P, Wan R, Huo W, Chang Z, 2018. Toxic effects of cyhalofop-butyl on embryos of the Yellow River carp (Cyprinus carpio var.): alters embryos hatching, development failure, mortality of embryos, and apoptosis. Environ. Sci. Pollut., 25(24): 24305-24315.

Zhu L, Mu X, Wang K, Chai T, Yang Y, Qiu L, Wang C, 2015. Cyhalofop-butyl has the potential to induce developmental toxicity, oxidative stress and apoptosis in early life stage of zebrafish (Danio rerio). Environ. Pollut., 203: 40-49. 